International Journal of Research in Advent Technology, Vol.7, No.4, April 2019

E-ISSN: 2321-9637

Available online at www.ijrat.org

\title{
Multiple Pipe Line Solar Instant Water Heater Using Reflecting Mirror
}

\author{
N.Sethupathi ${ }^{1}$, R.Sribal $^{2}$, K.Vikramprasad $^{3}$, P.Madeswaran $^{4}$ \\ Assistant Professor, PG \& Research Department of Physics, Arignar Anna Govt. Arts College, Namakkal- \\ 637002,Tamilnadu,India ${ }^{\text {. }}$. \\ M.Sc.,student, PG \& Research Department of Physics, Arignar Anna Govt. Arts College, Namakkal- \\ 637002,Tamilnadu,India². \\ Research Scholar,PG \&Research Department of Physics, Arignar Anna Govt. Arts College, Namakkal- \\ 637002,Tamilnadu,India ${ }^{3}$. \\ Assistant Professor, Department of Energy studies, Periyar University, Salem-636011, Tamilnadu, India ${ }^{4}$ \\ Corresponding Authoremail id-kvikramprasad89@gmail.com \\ sethupathi2011@gmail.com ${ }^{1}$,rsribal@gmail.com²,mades_saamy@yahoo.co.in ${ }^{3}$
}

\begin{abstract}
Solar water heating for domestic and industrial use is a processing and economical application of solar energy. There are numerous solar water heater systems used around the world for domestic water heating. Many companies in India to manufacture solar water heaters, but these are not becoming popular in the domestic sector because of their high cost. The purpose of this project work is to design, construction, outdoor testing, of simple and low cost compact solar instant water heating system. The most commonly used solar water heaters for domestic needs is the natural circulation and storage type. But, our proposed $\mathrm{U}$ shape pipeline solar instant water heater would be simple, low cost and quick heating device without storage tank. We can operate this heater on all sunny days from 9.AM to 4 .PM. Solar energy extensive research to be performed to further improve the thermal efficiency of this solar instant water heating in short time.
\end{abstract}

Keywords-Solar energy, Instant water heater, Pipeline, Reflecting mirror, Wind analysis.

\section{INTRODUCTION}

Sunlight bathed vitality is the brilliant light and warmth from the sun that is outfit utilizing a scope of regularly covering innovations, for example, sun powered warming. It is a critical wellspring of sustainable power source and its advances are comprehensively described as either aloof sun based or dynamic sun based, relying upon how they catch and disseminate sunlight based vitality or convert it into sun oriented power. Renewable energy is defined as the energy harnessed from natural, rapid, and frequent energy flows occurring at the earth's surface. Due to the inherent property of balance and reconstruction in nature, the energy extraction from clean, environmentally, and has no contribution to the global warming. Solar energy is a clean and environment, energy resource for sustainable developers. Solar energy provides an opportunity to reduce dependence on imported alternate to oil for production of electricity and an alternative to electricity and gas for various applications. Solar water heating systems have a widespread usage and applications in both domestic and industrial sectors. The system is generally installed on the roof or open ground with collector facing the sun and connected to a continuous water supply.
Warming of water is the most widely recognized utilization of sun Powered vitality on the planet. Water flows through the tubes, Absorbs heat and becomes hot and the heated water is stored in a tank for further use. Domestic water heating systems have shown to offer savings of about $70 \%$ to $90 \%$ of total water heating costs and hence are one of the best candidates to greatly reduce household energy consumption. Hot water is an essential requirement in industrial as well as in the domestic sector. It is required for taking baths and for washing clothes, utensils and other purposes, both in urban and rural areas. Water heating typically represents a high percentage of energy consumption in homes and businesses, when solar water heating system supplement or replace conventional water heaters they displace some or all of the fuel that would have been used in those systems. Due to the increasing prices of the primary energy resources and their associated serious environmental issues, the use of the renewable resources, especially, the solar energy is increasingly in demand in both developing and developed countries. Solar energy is the best source of energy for water

\section{EXPERIMENTALSETUP}

The experimental set up of the multiple pipe line solar instant water heater is shown a) Side view in fig $1.1 \mathrm{~b}$ ) Top view in fig 1.2. It consists of a storage tank, reflecting mirrors, connecting pipes and transparent mirror. In this experiment $6 \times 2$ feet, reflecting mirror 


\section{Available online at www.ijrat.org}

were placed at the bottom which acts as a light reflector for pipelines. In our study, seven numbers of galvanized iron pipes of five feet long were placed parallel and close together. The absorbing surface pipes were black painted and connected to each other by $U$ type bends which is supported by wooden stands $\left[^{2}\right]$. Front sides of the multiple pipelines were then covered with plain

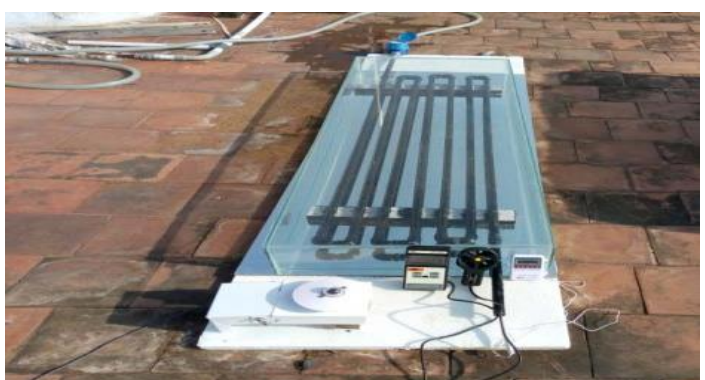

Fig.1.1 Side view of the multiple pipe line solar instant water heater using reflecting mirror.

\begin{tabular}{|l|l|}
\hline $\begin{array}{l}\text { S.N } \\
\mathrm{O}\end{array}$ & Fabrication material \\
\hline 1 & $\begin{array}{l}\text { feet length } 1 / 2 \quad \text { inch } \\
\text { diameter Galvanized Iron } \\
\text { seven numbersof } \\
\text { pipe. }\end{array}$ \\
\hline 2 & $\begin{array}{l}1 / 2 \text { inch bends to make U shape six } \\
\text { numbers of bend }\end{array}$ \\
\hline 3 & Reflecting Mirror \\
\hline 4 & Box type transparent glass \\
\hline 5 & Wooden stand \\
\hline 6 & Black Paint \\
\hline
\end{tabular}

Table 1. Instruments.

Glass with the size dimension of $5.75 \times 1.75 \times 0.5$ feet. Multiple pipe lines absorb solar radiation and the absorbed heat is transmitted to the water in the pipe. In this experiment we collected data on inlet temperature, outlet temperature, ambient temperature, wind velocity, solar radiation were discussed. The temperature of the inlet and outlet water was measured by two thermometers. The cold water is supplied to the inlet of the pipeline and we received hot water at the outlet pipe line with considerable increase in temperature $\left[{ }^{3}\right]$.

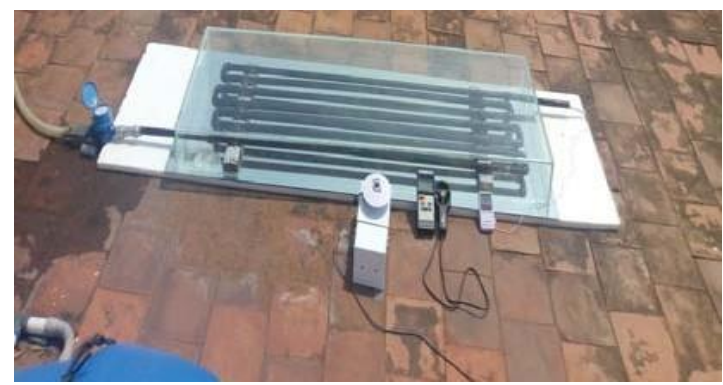

Fig.1.2Topviewofmultiplepipesolar instant water heater using a ready reflecting mirror.

\begin{tabular}{|l|l|l|}
\hline S.NO & $\begin{array}{l}\text { Instruments } \\
\text { used }\end{array}$ & Model \\
\hline 1 & Pyranometer & EU-08P \\
\hline 2 & Anemometer & AM4201 \\
\hline 3 & $\begin{array}{l}\text { Digital } \\
\text { Thermometers }\end{array}$ & ST9269B \\
\hline 4 & $\begin{array}{l}\text { Water Flow } \\
\text { meter }\end{array}$ & $\begin{array}{l}\text { AQURA17- } \\
18674\end{array}$ \\
\hline
\end{tabular}

Table 2. Fabrication Material. 
International Journal of Research in Advent Technology, Vol.7, No.4, April 2019 E-ISSN: 2321-9637

Available online at www.ijrat.org

\section{RESULT ANDDISCUSSIONS}

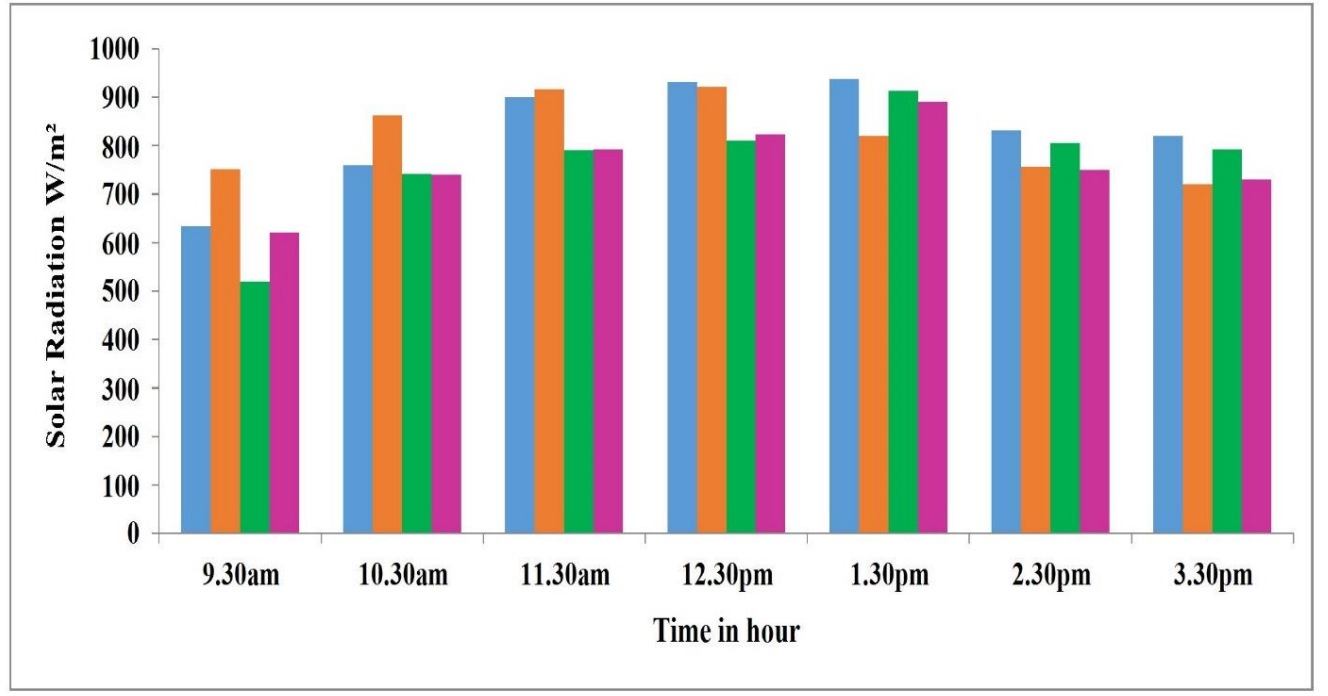

Fig.1.3 Time Vs Solar Radiation

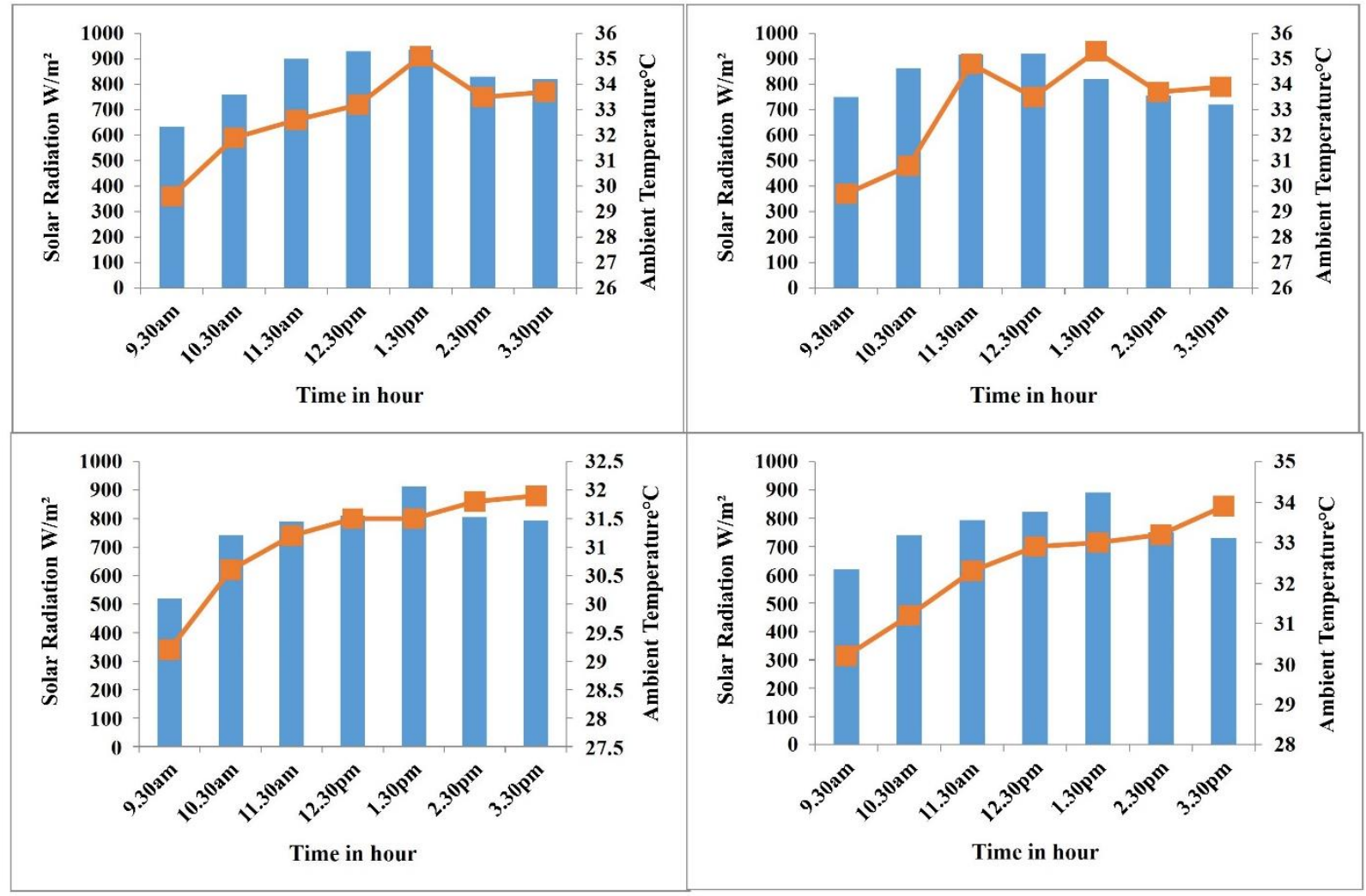

Fig .1.4 Time Vs Solar Radiation Vs Ambient Temperature 
International Journal of Research in Advent Technology, Vol.7, No.4, April 2019 E-ISSN: 2321-9637

Available online at www.ijrat.org

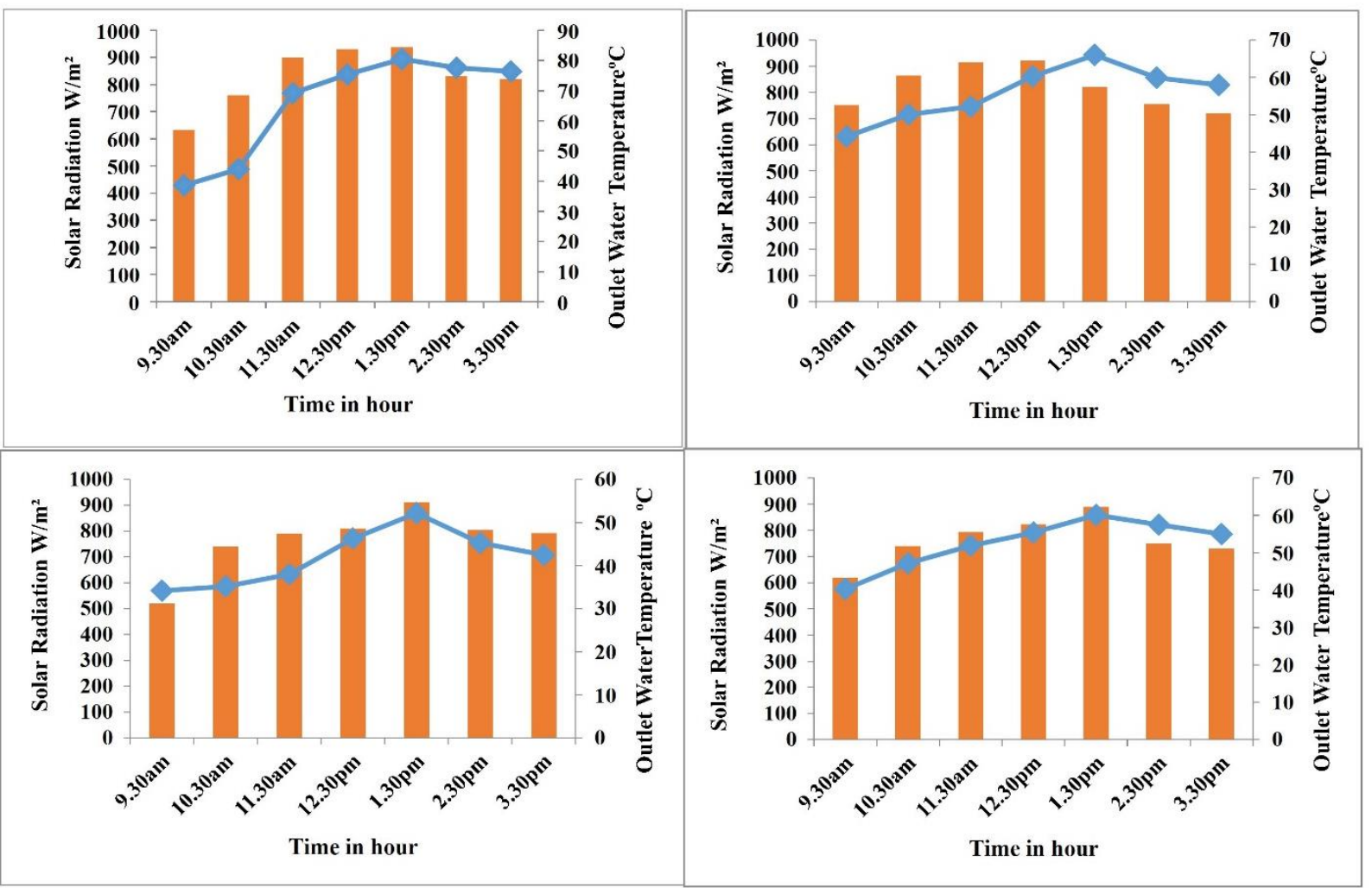

Fig.1.5 Time Vs Solar Radiation Vs Outlet Water Temperature

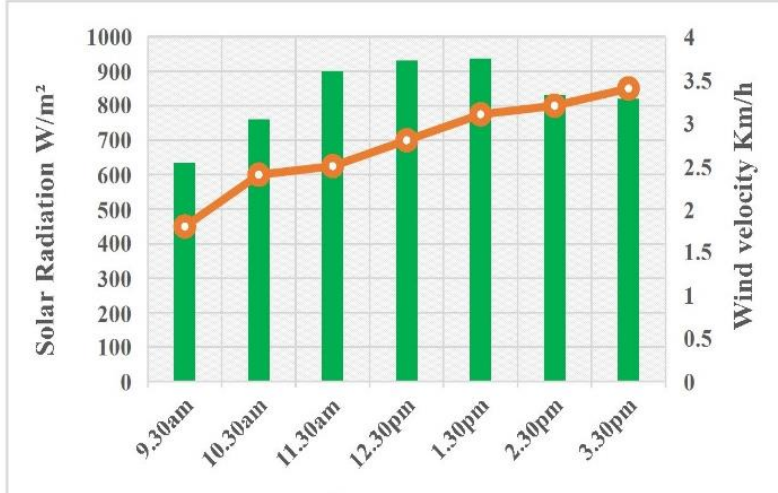

Time in hour

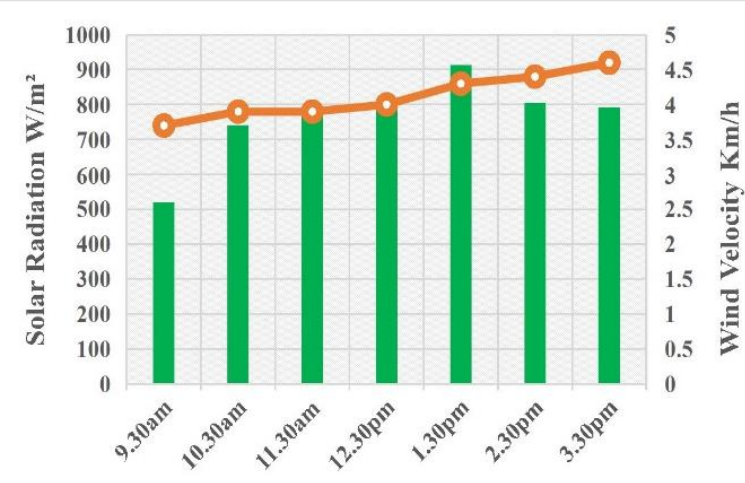

Time in hour

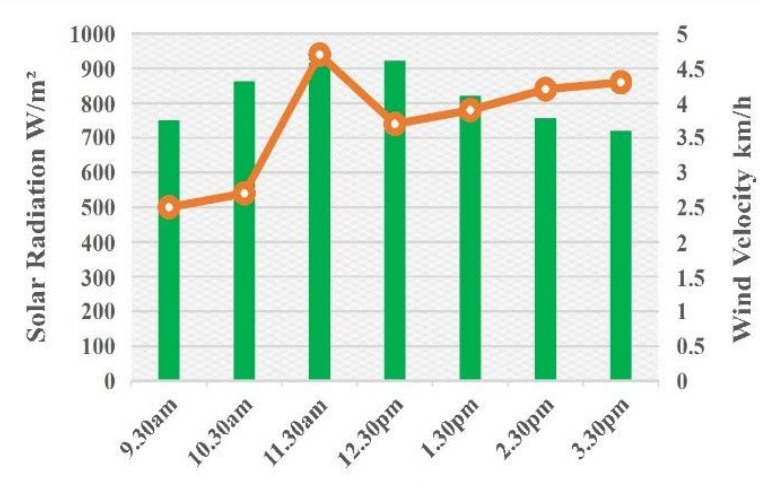

Time in hour

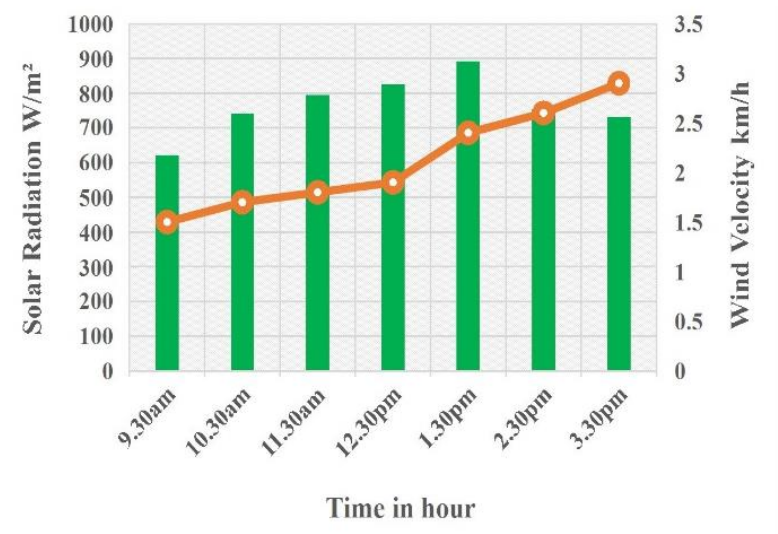

Fig.1.6Time Vs Solar Radiation Vs Wind Velocity 


\section{Available online at www.ijrat.org}

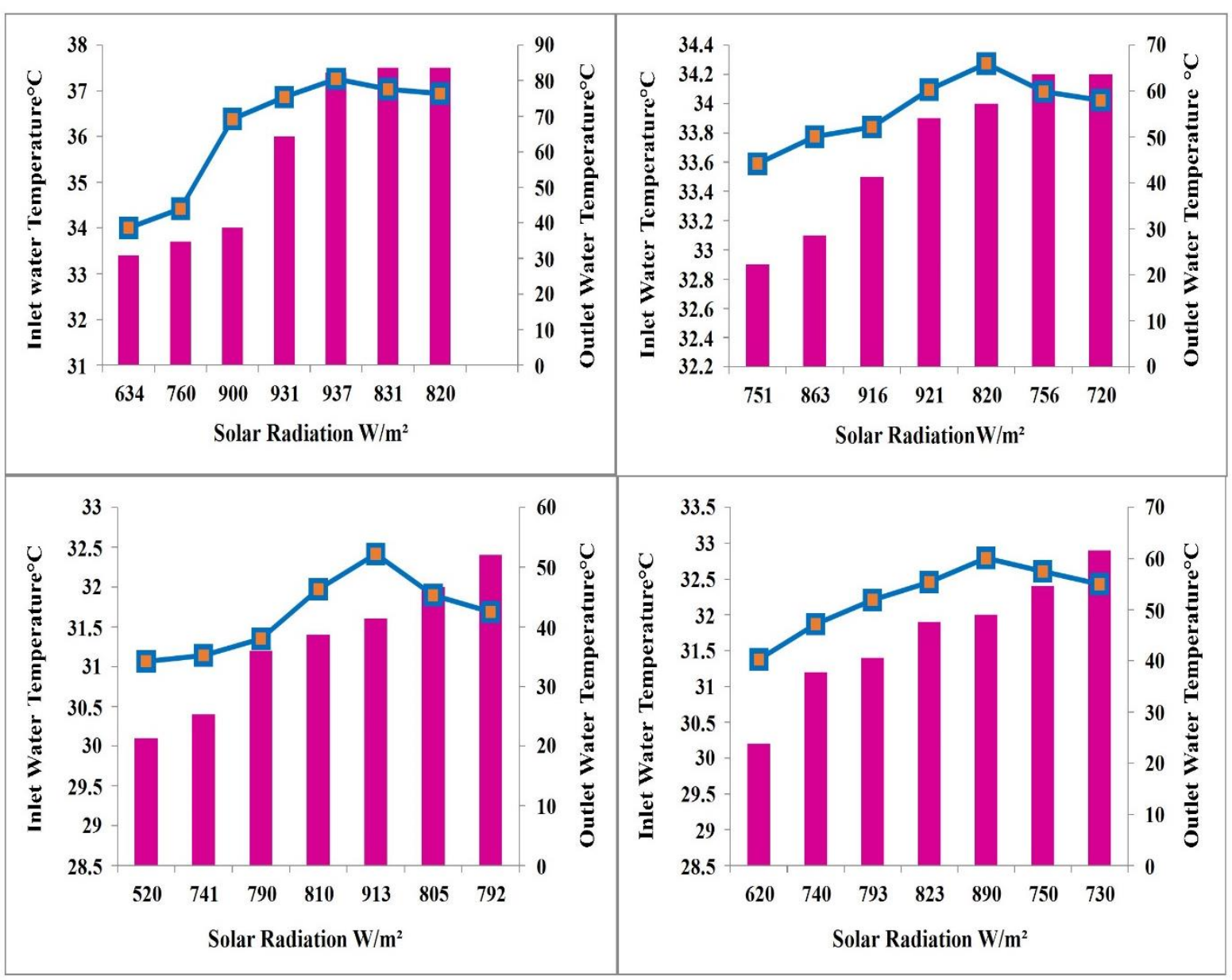

Fig.1.7 Solar Radiation Vs Inlet Water Temperature Vs Outlet Water Temperature

The experiments were performed on clear sky days in the month of February at different flow rates. Parameters such as solar radiations, inlet and outlet water temperatures, ambient temperature and wind velocity were collected manually. From the collected data, the results were discussed. Fig 1.3 shows the variation of solar radiation with respect to time for flow rate. From the graph it is shown that experiment starts at 9.30 am where the irradiation gradually increases and it is quite good between 11.30 am to 12.30 am thatis about $921 \mathrm{~W} / \mathrm{m}^{2}$.Withrespecttothe time it is observed that there is a constant increase in the solar radiation and then again it decreases. Fig.1.4 shows the time and ambient temperature during a typical clear summer condition $\left.{ }^{4}\right]$. It is observed thatambienttemperatureincreasedto $33^{\circ} \mathrm{C}$ at $12.30 \mathrm{pm}$.It is observed that the ambient temperature gradually increasing through period between 9.30am to3.30pm.Fig1.5 shows the variation of water flow rate with temperature. In this case the water flow increased with decrease in temperature. The maximum flow of 20 liters per hour was captured at temperature of $66^{\circ} \mathrm{c}$.Fromthisstudy, we found that our water heater is suitable for flow rate of 20 liters per hour. The average water flow rate is 30 liters at lowest temperature at $57^{\circ} \mathrm{c}$. Typically, short term daily wind performances are shown fig.1.6. In our study wind velocity is measured by using an anemometer for each and every one hour respectively from 9.30 am to $3.30 \mathrm{pm}$ with maximum wind speed of $4.6 \mathrm{~km} / \mathrm{HR}$. From this result, we can infer that wind velocity does not influence the solar radiation. Variation of water outlet and inlet temperature with respect to the maximumvalueradiationisshownfig.1.7. From the graph it is clear that the outlet temperature increased when solar radiation was increased $\left(890 \mathrm{~W} / \mathrm{m}^{2}\right)$. The increase of outlet temperature of water with maximum capacity may be achieved by increasing the number of $U$ shape pipelines from 7 to 30 numbers. If we increase the pipe lines to30numberswecangetmorethan 100 liters/hour with the temperature of $70^{\circ} \mathrm{c}$. We can also increase the outlet temperature of this heater by change the 


\section{Available online at www.ijrat.org}

size of the pipe lines from half inch to one inch diameter $\left[{ }^{5}\right]$.

\section{CONCLUSION}

The multiple pipeline solar instant water heater using reflecting mirror has been fabricated and the performance test was conducted. This solar instant water heater ensures that maximum output can take up 20 liters of water at $60^{\circ} \mathrm{C}$ per hour. During the performance studies between 850 to $1000 \mathrm{~W} / \mathrm{m}^{2}$ solar irradiations and the wind velocity between $2 \mathrm{~m} / \mathrm{s}$ to $3.3 \mathrm{~m} / \mathrm{s}$, we obtained the maximum output temperature. The thermal losses are minimized according to wind velocity studies. This system is simple low cost and eco friendly. Our water heater is easy to construct, maintenance free and also very effective for domestic and industrial uses such as homes, hotels, hospitals and mass-production and service industries. This system also helps to reduce the consumption of electric power in domestic and industries sectors.

Future work: We have planned to increase the efficiency of our multiple pipe line instant solar water heater by adding the suitable reflectors and adding additional pipelines with increasing the size from half inch to one inch diameter.

\section{REFERENCES}

[1]A.W.Culp, "Principles of energyconversion" , $13^{\text {th }}$ ed.,vol.2.Mcgraw-hillinc: Unitedstates, 1979,pp.568.

[2]N.Sethupathi,K.Vikramprasad,P.Mahalingam,a ndP.Maadeswaran."Designandconstructionof a new Bin Model solar instant water heater". International journal of research in advent technology, 6,3260-3264,2018.

[3]N.Sethupathi ,K.Vikramprasad, and P.Maadeswaran. "A Review on efficiency factorsand equations of various solar water heaters and their relative field components".Rasayan journal of chemistry, 10:778-783,2017.

[4]E.Azad,"Therotical and experimental investigate on of heat collector". Experimental thermal fluid sciences, 32:1666-1672,2008.

[5]K.S.Ong, W.L Tong and J.K. Choong. "Performance of U-tube solar water heater with vertical and inclined panels". International journal of low-carbon technologies,doi:10.1093,2013. 